Maurer School of Law: Indiana University

Digital Repository @ Maurer Law

2012

\title{
What Do Courts Have to Do With It?: The Judiciary's Role in Making Federal Tax Law
}

Leandra Lederman

Indiana University Maurer School of Law, Ilederma@indiana.edu

Follow this and additional works at: https://www.repository.law.indiana.edu/facpub

Part of the Tax Law Commons

\section{Recommended Citation}

Lederman, Leandra, "What Do Courts Have to Do With It?: The Judiciary's Role in Making Federal Tax Law" (2012). Articles by Maurer Faculty. 799.

https://www.repository.law.indiana.edu/facpub/799

This Article is brought to you for free and open access by the Faculty Scholarship at Digital Repository @ Maurer Law. It has been accepted for inclusion in Articles by Maurer Faculty by an authorized administrator of Digital Repository @ Maurer Law. For more information, please contactrvaughan@indiana.edu. 


\title{
WHAT DO COURTS HAVE TO DO WITH IT?: THE JUDICIARY'S ROLE IN MAKING FEDERAL TAX LAW
}

\author{
Leandra Lederman
}

\begin{abstract}
The Internal Revenue Code is an important source of federal tax law, but it is not the only source. The U.S. Department of the Treasury and Internal Revenue Service issue important guidance, and federal courts interpret all of these authorities. This essay provides an overview of federal tax litigation, at both the trial and appellate levels, and discusses the interplay among Congress, the Treasury, and the judiciary in developing federal tax law.
\end{abstract}

Keywords: tax law, tax litigation, courts, Treasury, IRS

JEL Codes: K34, K41

\section{INTRODUCTION}

- he Internal Revenue Code (Code) generally is the first place to look when confronting a federal tax question, but it is important to recognize that much federal tax law is not statutory. The U.S. Department of the Treasury (Treasury) promulgates regulations, and the Internal Revenue Service (IRS) issues important guidance, such as Revenue Rulings, Revenue Procedures, and Notices (Hickman, 2009). Federal courts interpret all of these authorities. In order to understand and apply federal tax law, it is important to appreciate the role that federal trial courts, Courts of Appeals, and the U.S. Supreme Court play in developing the law. This essay provides an overview of federal tax litigation, discusses the deference courts give to guidance issued by the Treasury and IRS, and discusses when taxpayers have "standing" to challenge the tax laws in court. The essay also discusses cases in which Congress may step in to amend the Code following a court decision.

\section{BACKGROUND ON FEDERAL TAX LITIGATION}

Federal tax controversies involve disputes between taxpayers and the IRS. Like other kinds of litigation, they may raise factual issues, legal issues, or both. In many cases, the court hearing the case considers not only any governing statute or statutes, but also 
relevant Treasury and IRS guidance. Courts also take account of applicable case law. There are a variety of types of federal tax cases, but many of them involve a disagreement as to the amount of the tax liability (Cords, 2008). Most of these cases - over 95 percent $^{1}$ (Laro, 1995) - are heard by the U.S. Tax Court, which "has jurisdiction to redetermine income, gift, estate, and certain excise tax deficiencies" (Cords, 2008, p. 436). Non-deficiency cases in the Tax Court may involve, for example, collection issues or the defense to liability of "innocent spouse" status (Cords, 2008, p. 436 and fn. 43).

Disputes over a tax deficiency often originate from an IRS audit, though they may also arise when a taxpayer amends its return to claim a refund of amounts previously paid. When a dispute arises out of an audit, the IRS cannot assess the tax without first sending the taxpayer a letter known as a "Notice of Deficiency" or "statutory notice." The notice gives the taxpayer the option to petition the Tax Court, so it is sometimes also termed the "ticket to Tax Court" (Lederman, 1996). The Tax Court has jurisdiction not only over the deficiency, but also to consider any overpayment claimed by the taxpayer in its petition. ${ }^{3}$

The IRS's mailing of the Notice of Deficiency also starts a "prohibited period" during which the IRS is prohibited from assessing tax. ${ }^{4}$ If the taxpayer petitions the Tax Court, the "prohibited period" continues until the Tax Court's decision is final. That includes the time until all appeals have run. ${ }^{5}$ If the taxpayer does not timely petition the Tax Court, the IRS will assess the tax.

Rule 91(a)(1) of the Tax Court's Rules of Practice and Procedure requires parties to stipulate to the facts to the fullest extent possible. The court's rules also permit the parties to submit cases fully stipulated. ${ }^{6}$ Accordingly, Tax Court trials generally focus on contested issues. Tax Court trials are overseen by a judge, not a jury, and are held in numerous cities around the United States (Lederman and Mazza, 2009, p. 297). ${ }^{7}$ The

\footnotetext{
1 For example, in 2010, there were approximately 29,600 cases pending in Tax Court, 700 in the District Courts, and 500 in the Court of Federal Claims, making Tax Court cases 96.1 percent of the total (Report of Office of Chief Counsel, Internal Revenue Service, American Bar Association Tax Section Court Procedure Committee, FY 2011, http://www.americanbar.org/content/dam/aba/events/taxation/taxiq-11 mid-032. authcheckdam.pdf (calculation by the author)). Similarly, in 2011, Tax Court cases were 96.5 percent of the total (Report of Office of Chief Counsel, Internal Revenue Service, American Bar Association Tax Section Court Procedure Committee, FY 2011, http://www.americanbar.org/content/dam/aba/events/taxation/taxiq-mid12-butler-impdev-irs-slides.authcheckdam.pdf (calculation by the author)).

2 See I.R.C. $\$ 6213(\mathrm{a})$.

3 See I.R.C. $§ 6512$ (b)(1). The amount of any overpayment that the Tax Court can order to be refunded is capped by statute in an effort at parallelism with the statute of limitations on refund claims. See I.R.C. $\S$ 6512(b)(3).

${ }^{4}$ See I.R.C. $\$ 6213(a)$.

5 See I.R.C. $\$ 7481$.

6 See U.S. Tax Court Rules of Practice \& Procedure, 122(a).

7 Section 7445 of the Internal Revenue Code of 1986 and the Tax Court Rules of Practice \& Procedure, Rule 10(b), both state, "[t]he principal office of the Tax Court shall be in the District of Columbia, but the Tax Court or any of its divisions may sit at any place within the United States." For a list of the usual places Tax Court trials are held, see U.S. Tax Court, "Places of Trial," http://www.ustaxcourt.gov/dpt_cities.htm.
} 
taxpayer is expected to request a place for trial at the time of filing the petition. If the taxpayer does not do so, the IRS is expected to make such a request in conjunction with its answer. ${ }^{8}$ Tax Court practice is also distinct from most courts in that briefs are filed after trial, rather than before trial. ${ }^{9}$

Most opinions in regular Tax Court cases are Memorandum Opinions, which are not official pronouncements of the Tax Court, have little precedential value, and are privately published. ${ }^{10}$ Some opinions are Division Opinions (sometimes referred to as "full T.C.s"); they have precedential value and are officially published (Cohen, 2001). The Chief Judge decides whether a particular opinion will be a Division Opinion or a Memorandum Opinion. ${ }^{11}$

Some Tax Court cases are reviewed by the full court in conference. Those decisions are always issued as Division Opinions and include a statement that they were reviewed. They may contain a majority opinion, concurrences, and dissenting opinions. Generally speaking, decisions receive review by the full court when they: (1) decide issues not previously considered by the court; (2) invalidate a Treasury Regulation; (3) would conflict with existing Tax Court decisions; (4) involve an issue not previously considered by the Tax Court and would conflict with the decision of a Court of Appeals other than the one to which appeal would lie; or (5) involve an issue on which the Tax Court has been reversed by a court other than the one with jurisdiction over any appeal (Crimm, 1999).

If a Tax Court case has less than $\$ 50,000$ in issue for each tax year, the taxpayer can request to have the Tax Court to hear it as a "small tax case" (or "S case"). ${ }^{12}$ The case will then be docketed as an $\mathrm{S}$ case, but " $[\mathrm{t}]$ he Court, on its own motion or on the motion of a party to the case, may, at any time before the trial commences, issue an order directing that the small tax case designation be removed and that the proceedings not be conducted as a small tax case." 13 Small tax cases are considered under more relaxed rules of procedure and evidence, but decisions in them are not appealable. ${ }^{14}$ Opinions in small tax cases are called Summary Opinions, and they have no precedential value. Because the opinions in $\mathrm{S}$ cases have no precedential value, occasionally the Tax Court will move a case out of S case status into the regular procedure if it appears to have broad importance (Nelson and Keightley, 1988). As of fiscal year 2011, S cases comprised 39.6 percent of the Tax Court's docket. ${ }^{15}$

\footnotetext{
${ }^{8}$ See U.S. Tax Court Rules of Practice \& Procedure, 140(a).

${ }^{9}$ See U.S. Tax Court Rules of Practice \& Procedure, 151(a).

${ }^{10}$ See Nico v. Commissioner, 67 T.C. 647, 654 (1977), affirmed in part and reversed in part on other grounds, 565 F.2d 1234 (2d Cir. 1977), noting that Tax Court memorandum opinions do not serve as controlling precedent.

${ }^{11}$ See I.R.C. $\S 7460$.

${ }^{12}$ See I.R.C. § 7463(a); U.S. Tax Court Rules of Practice \& Procedure, Rule 171(a).

${ }^{13}$ U.S. Tax Court Rules of Practice and Procedure, Rule 171(d).

${ }^{14}$ See I.R.C. 7463(a), (b).

${ }^{15}$ See "Report of Office of Chief Counsel, Internal Revenue Service, American Bar Association Tax Section Court Procedure Committee, FY 2011," http://www.americanbar.org/content/dam/aba/events/taxation/ taxiq-mid12-butler-impdev-irs-slides.authcheckdam.pdf.
} 
The Tax Court is not the only court that hears federal tax cases. For example, if the taxpayer has filed a bankruptcy petition, a bankruptcy court has jurisdiction to "determine the amount or legality of any tax, any fine or penalty relating to a tax, or any addition to tax, whether or not previously assessed, whether or not paid,"16 unless the issue was "adjudicated by a judicial or administrative tribunal of competent jurisdiction before the commencement of the [bankruptcy] case." ${ }^{" 17}$ If an action is pending in Tax Court at the time the taxpayer files a bankruptcy petition, the bankruptcy court determines whether it or the Tax Court will hear the case (Germain, 2004). If the converse is the case - during a pending bankruptcy action, the taxpayer receives a Notice of Deficiency - Tax Court precedent generally provides that it can consider the deficiency issues, but not the question of whether the tax debt was discharged in bankruptcy. ${ }^{18}$

Bankruptcy is something of a special situation in that it applies to a subset of taxpayers, but it is a context in which taxpayers can resolve their substantive tax disputes before having to pay the tax. The other alternatives to Tax Court involve fully paying the tax and then seeking a refund, either in U.S. District Court or in the U.S. Court of Federal Claims. ${ }^{19}$ To pursue this refund route, the taxpayer must pay in full the tax the IRS has claimed is due ${ }^{20}$ and then must follow the refund procedures, starting with timely filing a refund claim. ${ }^{21}$ The taxpayer may not file suit for a refund until either six months have elapsed from the filing of the claim or the IRS mails the taxpayer a notice of disallowance. ${ }^{22}$ The taxpayer also faces an outside limit on the time to file suit of two years from the date the IRS mails the notice of disallowance. ${ }^{23}$

Far fewer cases are litigated in the refund courts than in Tax Court (Table 1). ${ }^{24}$ The main reason for that is likely the fact that the taxpayer must prepay before pursuing a refund suit, whereas, in Tax Court, the taxpayer need not prepay the deficiency (Laro, 1995). In addition, the Notice of Deficiency informs taxpayers of the Tax Court option and the deadline to file there but says nothing about the refund option, which may result in some unrepresented taxpayers assuming that the Tax Court route is the only one

${ }^{16}$ See 11 U.S.C. $\$ 505(a)$.

${ }^{17}$ See 11 U.S.C. $\$ 505(\mathrm{a})(2)(\mathrm{A})$, providing that the bankruptcy court may not determine, among other things, "the amount or legality of a tax, fine, penalty, or addition to tax if such amount or legality was contested before and adjudicated by a judicial or administrative tribunal of competent jurisdiction before the commencement of the case under this title ...."

${ }^{18}$ See, e.g., Moody v. Commissioner, 95 T.C. 655, 658 (1990); Nielson v. Commissioner, 94 T.C. 1, 8 (1990); and Germain, 2004. By contrast, the Tax Court has held that it in can consider in the context of a postcollection proceeding the question of whether a tax debt was discharged in bankruptcy. See Washington $v$. Commissioner, 120 T.C. 114, 120 (2003), which involved a lien proceeding under Code section 6320, and see Neal Swanson v. Commissioner, 121 T.C. 111, 117 (2003), which involved a levy proceeding under Code section 6330 .

${ }^{19}$ See 28 U.S.C. $\$ 1346(a)(1)$.

${ }^{20}$ Flora v. United States, 362 U.S. 145 (1960).

${ }^{21}$ See I.R.C. $§ 7422$ (a). The statute of limitations on refund claims generally gives the taxpayer the longer of three years from the time the return was filed or two years from the tax was paid. See I.R.C. $§ 6511$.

${ }^{22}$ See I.R.C. $§ 6532(a)(1)$. The taxpayer may also waive disallowance. See I.R.C. § 6532(a)(3).

${ }^{23}$ See I.R.C. $§ 6532(a)(1)$.

${ }^{24}$ See the text accompanying footnote 36 . 
available. ${ }^{25}$ In regular Tax Court cases, many taxpayers represent themselves. For example, in 2011, there were 14,907 non-S case petitions, of which 9,750 , or 65.4 percent were pro se. ${ }^{26} \mathrm{In} \mathrm{S}$ cases, the overwhelming majority of taxpayers proceed pro $s e .{ }^{27}$ Some initially unrepresented taxpayers hire counsel after filing a Tax Court petition, but once the case is docketed in Tax Court, it cannot be removed to another court or voluntarily dismissed (Lederman, 2001). As Table 1 reflects, the courts' inventory of cases has fluctuated over time.

Tax Court decisions generally are appealable to the Court of Appeals for the Circuit within which the taxpayer resided (or had its principal place of business or principal office) at the time the petition was filed. ${ }^{28}$ The Tax Court is an interesting position because it is a national trial court whose decisions are reviewable by multiple circuits. It is possible, for example, that a judge could decide the consolidated cases of multiple parties, each of whom appeal to different circuits. ${ }^{29}$ The Tax Court has held that it will "follow a Court of Appeals decision which is squarely in point where appeal from our decision lies to that Court of Appeals and to that court alone." ${ }^{30}$ Otherwise, the Tax Court is free to establish its own rule or follow its own precedent. ${ }^{31}$

District Court cases are appealable to the Courts of Appeals for the particular circuit in which they are located ${ }^{32}$ Court of Federal Claims decisions are appealable to the

${ }^{25}$ See Lederman and Mazza (2009), reproducing a Notice of Deficiency, which includes two paragraphs about filing a petition in Tax Court and nothing about pursuing refund procedures. A provision not included in the Code (an off-Code provision) requires that the Notice of Deficiency also specify the date that is the last day to timely petition the Tax Court. See Internal Revenue Service Restructuring and Reform Act of 1998, Pub. L. 105-206, § 3463(a), 112 Stat. 685, 767 (1998).

${ }^{26}$ See "Report of Office of Chief Counsel, Internal Revenue Service, American Bar Association Tax Section Court Procedure Committee, FY 2011," http://www.americanbar.org/content/dam/aba/events/taxation/ taxiq-mid12-butler-impdev-irs-slides.authcheckdam.pdf (calculations by the author).

${ }^{27}$ For example, in 2010, there were 13,747 pro se $\mathrm{S}$ case petitions and 1,250 represented $\mathrm{S}$ case petitions, and in 2011, there were 13,483 pro se S case petitions and 1,303 represented S case petitions. See "Report of Office of Chief Counsel, Internal Revenue Service, American Bar Association Tax Section Court Procedure Committee, FY 2011," http://www.americanbar.org/content/dam/aba/events/taxation/taxiq-mid12-butlerimpdev-irs-slides.authcheckdam.pdf. The ratio in each of those years is not unusual. See "Report of Office of Chief Counsel, Internal Revenue Service, American Bar Association Tax Section Court Procedure Committee, FY 2011," http://www.americanbar.org/content/dam/aba/events/taxation/taxiq-mid12-butlerimpdev-irs-slides.authcheckdam.pdf.

${ }^{28}$ See I.R.C. $\S 7482(\mathrm{~b})(1)$.

${ }^{29}$ See, e.g., Investment Research Assoc. v. Comm 'r, T.C. Memo. 1999-407. That case has multiple lines of subsequent history. The Court of Appeals for the Eleventh Circuit affirmed. See Ballard v. Comm'r, 321 F.3d 1037 (11th Cir. 2003). The Court of Appeals for the Fifth and Seventh Circuits affirmed in part and reversed in part. See Lisle v. Comm 'r, 341 F.3d 364 (5th Cir. 2003); Estate of Kanter v. Comm'r, 337 F.3d 833 (7th Cir. 2003). The Kanter and Ballard cases made it to the U.S. Supreme Court. See Ballard v. Comm'r, 544 U.S. 40 (2005).

${ }^{30}$ Golsen v. Comm'r, 54 T.C. 742 , 757 (1970), aff'd on other grounds, 445 F.2d 985 (10th Cir. 1971).

${ }^{31}$ See Golsen at 757, stating that "[w]e shall remain able to foster uniformity by giving effect to our own views in cases appealable to courts whose views have not yet been expressed, and, even where the relevant Court of Appeals has already made its views known, by explaining why we agree or disagree with the precedent that we feel constrained to follow."

${ }^{32}$ See 28 U.S.C. $\S 1294(1)$. 


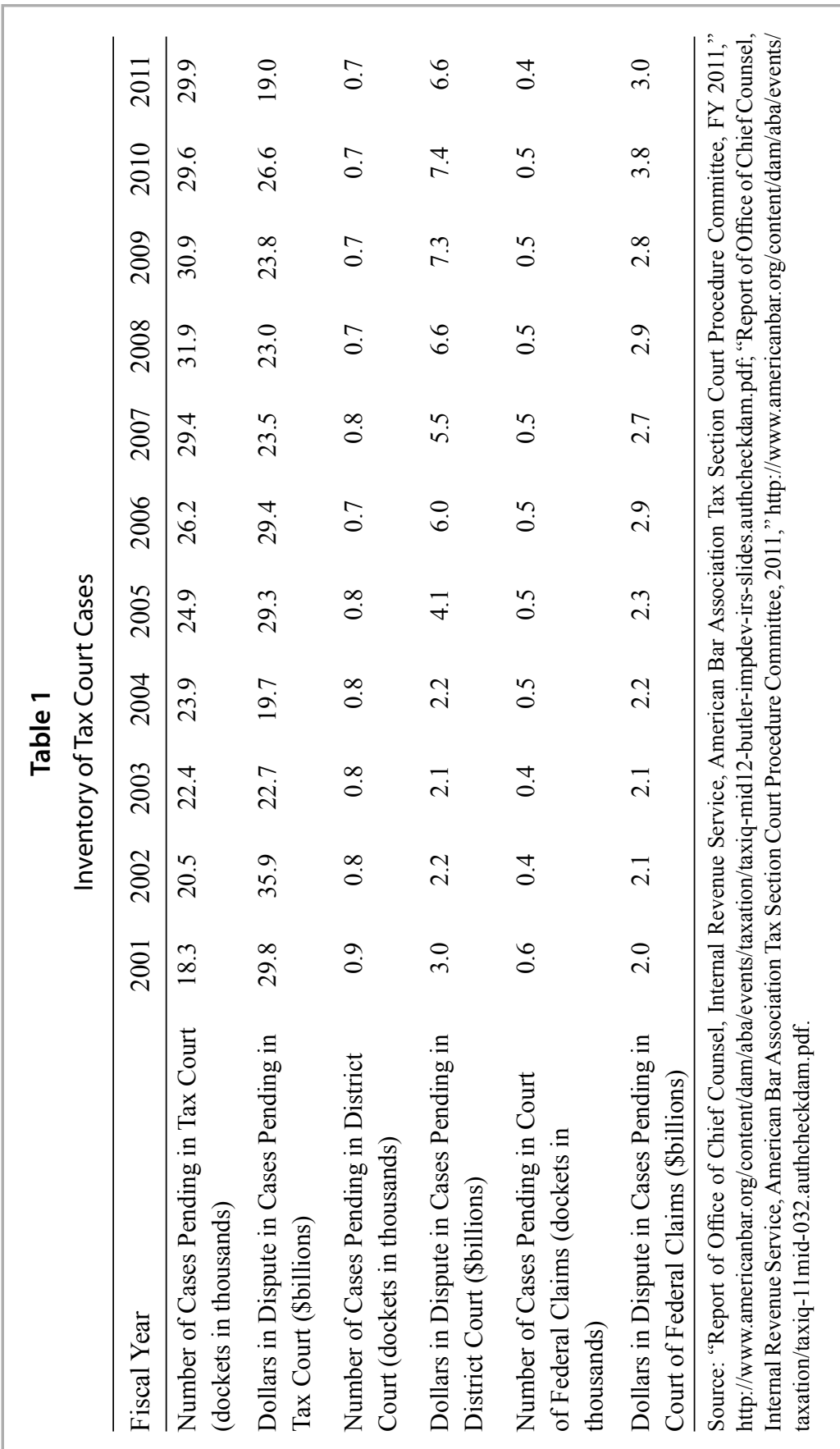


Court of Appeals for the Federal Circuit. ${ }^{33}$ Under U.S. Supreme Court Rule 10, Court of Appeals decisions are appealable to the U.S. Supreme Court, which has discretion to grant a writ of certiorari.

A Supreme Court decision is binding precedent for all lower courts. ${ }^{34}$ However, Congress can change the law by amending the Code if it disagrees with the Supreme Court's decision. Although Congress changes the tax law frequently, and taxpayers then respond to the new laws, instances of Congress acting promptly to change the law interpreted in a court decision are not particularly frequent. One study found that "[o] $\mathrm{n}$ average, the likelihood of a congressional response to a case in the first year after decision is $3 \%$," though a quick response is much more likely in cases involving lobbyists, a Supreme Court invitation for oversight, and other factors (Staudt, Lindstadt, and O'Connor, 2007, pp. 1381-1382).

A famous example of a speedy Congressional reaction to a Supreme Court decision involves Gitlitz v. Commissioner: ${ }^{35}$

In Gitlitz v. Commissioner, an insolvent S Corporation was relieved of its debt. Pursuant to Code $\S 108(\mathrm{a})(1)(\mathrm{B})$, the S Corporation excluded the amount of the discharge. Contending that debt relief to an insolvent taxpayer is income, even if it is excluded from gross income, the taxpayer treated the amount relieved as an "item of income" and increased his basis by that amount. After increasing his basis, the taxpayer deducted his share of previously suspended net operating losses. The deductibility of these losses was the ultimate issue (Smith, 2007, p. 50).

The Supreme Court held that the taxpayer could increase his basis by the excluded amount and use that basis to deduct the suspended losses. ${ }^{36}$ However, the following year, Congress amended the Code to change that result prospectively. ${ }^{37}$

${ }^{33}$ See 28 U.S.C. $\S 1295(a)(3)$.

34 "In the American system, if an issue under consideration has been directly decided by the Supreme Court, lower courts are bound to reach the same result, "unless and until [the Supreme] Court reinterprets the binding precedent."' (Jois, 2009, p. 66, quoting Agostini v. Felton, 521 U.S. 203, 238 (1997)).

${ }^{35}$ See 531 U.S. 206 (2001). An older example involves Higgins v. Commissioner, 312 U.S. 212 (1941), which disallowed the deduction of the expenses involved in managing an investment portfolio as not incurred in a trade or business. Congress reacted by enacting Code section 212, which allows the deduction of investment expenses (Sanchirico, 2008). Unusually, the new section was made retroactive so that it applied to Mr. Higgins. See 56 Stat. 819, I.R.C. $\$ 23$ note which states that "For the purposes of the Revenue Act of 1938 or any prior revenue Act the amendments made to the Internal Revenue Code by this section shall be effective as if they were a part of such revenue Act on the date of its enactment."

${ }^{36}$ Gitlitz v. Comm'r, 531 U.S. 206, 218 (2001).

${ }^{37}$ See The Job Creation and Worker Assistance Act of 2002 (JCWAA), Pub. L. No. 107-147, 116 Stat. 21, $40 \S 402$ (a) (codified as amended at I.R.C. § 108(d)(7)(A)). Chapman (2002, p. 1202) explained: "Section 402(a) of the JCWAA amends 108(d)(7)(A) to provide that, in applying 108 at the corporate level, excluded discharge of indebtedness income does not pass through to the shareholders under 1366. It follows, therefore, that shareholders' bases are not increased under 1367. The losses suspended under 1366(d) are not available because they are reduced under 108(b)(2)(A) by the amount of the excluded discharge of indebtedness income." 


\section{ADMINISTRATIVE GUIDANCE AND JUDICIAL DEFERENCE}

Part II discussed federal tax litigation generally and possible Congressional response to court decisions. As indicated above, the courts apply not only the Code and prior court decisions, but also administrative guidance issued by the Treasury and the IRS. The Treasury has a general grant of authority to "prescribe all needful rules and regulations for the enforcement of [the Code], including all rules and regulations as may be necessary by reason of any alteration of law in relation to internal revenue." ${ }^{38}$ The Treasury produces dozens of regulations each year (Hickman, 2007, p. 1730), but sometimes fails for decades to promulgate regulations explicitly called for by statute (Gall, 2003, p. 413).

Although the Treasury has not always followed general administrative law principles, regulations generally are subject to the Administrative Procedure Act's requirement of notice to the public and an opportunity to comment (Aprill, 2012). As discussed above, the IRS also produces guidance..$^{39}$ Guidance that does not have the "force of law" is not subject to the notice-and-comment requirement and is therefore quicker to produce (Hickman, forthcoming).

The courts generally apply the administrative guidance produced by the IRS and Treasury, though they typically accord Treasury Regulations more deference than IRS guidance (Lederman, 2012). The U.S. Supreme Court recently made clear that the substantial deference established in the leading Chevron case applies to Treasury regulations regardless of whether they were promulgated under the general authority of Code section 7805 or under the authority of a specific statute to which the regulations relate. ${ }^{40}$ Chevron provides a two-step process:

First, always, is the question whether Congress has directly spoken to the precise question at issue. If the intent of Congress is clear, that is the end of the matter; for the court, as well as the agency, must give effect to the unambiguously expressed intent of Congress. If, however, the court determines Congress has not directly addressed the precise question at issue, the court does not simply impose its own construction on the statute, as would be necessary in the absence of an administrative interpretation. Rather, if the statute is silent or ambiguous with respect to the specific issue, the question for the court is whether the agency's answer is based on a permissible construction of the statute. ${ }^{41}$

The level of deference due guidance such as Revenue Rulings and Revenue Procedures is less clear, but most commentators agree that they warrant analysis under the

${ }^{38}$ I.R.C. $\S 7805$ (a). For more on the regulations process, see Mann (2012).

${ }^{39}$ Mann (2012, p. 896) observes that, "Over the last three years, the Internal Revenue Bulletin index shows the publication of 103 revenue rulings, 169 revenue procedures and 292 notices."

${ }^{40}$ Mayo Found. for Med. Educ. \& Research v. United States, 131 S. Ct. 704, 711-15 (2011).

${ }^{41}$ Chevron U.S.A., Inc. v. Natural Resources Defense Council, Inc., 467 U.S. 837, 842-43 (1984) (footnotes omitted). 
less deferential Skidmore case ${ }^{42}$ which provided that the respect due "will depend upon the thoroughness evident in its consideration, the validity of its reasoning, its consistency with earlier and later pronouncements, and all those factors which give it power to persuade, if lacking power to control." ${ }^{43}$

Although Treasury regulations receive substantial deference, courts do sometimes invalidate them. Several recent cases that have done so relate to time limitations. For example, in Swallows Holding v. Commissioner, the Tax Court considered a regulation that

interpret[ed] section 882(c)(2) to provide that a foreign corporation generally is entitled to deduct its expenses only if it files a timely return. Under the relevant part of the disputed regulations, a return is timely if it is filed before an arbitrary 18-month deadline ... devised by the Secretary. The Secretary issued the disputed regulations stating that section 882(c)(2) contains a "clear" requirement that a foreign corporation file its return timely in order to deduct its expenses. ${ }^{44}$

The Tax Court found the regulations invalid as inconsistent with the plain language of the statute ${ }^{45}$ The decision was reversed on appeal, with the Court of Appeals for the Third Circuit finding that the regulation should have been given deference under Chevron because the statute was ambiguous. ${ }^{46}$

In Lantz v. Commissioner, the Tax Court considered a regulation that imposed a twoyear filing deadline on a claim for equitable relief from joint and several liability for taxes arising out of a return filed jointly by a married couple. ${ }^{47}$ The other portions of the statute contained limitations periods, but the equitable relief provision was silent on whether a deadline applied. ${ }^{48}$ Because the case was appealable to the Seventh Circuit, which applied Chevron deference, the Tax Court considered the issue under that standard. ${ }^{49}$

\footnotetext{
${ }^{42}$ See Lederman (2012, p. 667); see also Hickman (2009, p. 260), noting that "[s]ince the Court's decision in [United States v.] Mead [Corp., 533 U.S. 218 (2001)], most courts and commentators have assumed or concluded that Skidmore provides the appropriate evaluative standard for revenue rulings . . . although not everyone agrees" (footnotes omitted). Hickman (2009, p. 260) has questioned that view arguing that Revenue Rulings may have "force of law" status and thus be eligible for Chevron deference, just as Treasury Regulations are (see also Hickman, forthcoming).

${ }^{43}$ See Skidmore v. Swift \& Co., 323 U.S. 134 (1944).

${ }^{44}$ See 126 T.C. 96, 98-99 (2006) (reviewed by the court) (footnote omitted), rev'd 515 F.3d 162 (3rd Cir. 2008).

${ }^{45}$ Swallows Holding at 132. This case was decided before Mayo Foundation, and the court also applied the deference standard of Natl. Muffler Dealers Association v. United States, 440 U.S. 472 (1979). See Swallows Holding at 129-30.

${ }^{46}$ See 515 F.3d 162, 167, 171 (3rd Cir. 2008) [hereinafter Swallows Holding II]. The Court of Appeals framed the issue as follows: "The crucial issue before us is whether the Tax Court erred in applying National Muffler rather than Chevron when evaluating the validity of Treas. Reg. 1.882-4(a)(3)(i)." Swallows Holding II at 167.

${ }^{47}$ See 132 T.C. 131 (2009) (reviewed by the court), rev'd, 607 F.3d 479 (7th Cir. 2010).

${ }^{48}$ Lantz at 134 (contrasting IRC $\S \S 6015(b)$ and (c) with IRC $\S$ 6015(f)).

${ }^{49}$ Lantz at 137.
} 
It found that imposing a time limit was contrary to the statute under Chevron step one, but that even if it were to reach step two, "the regulation is impermissible because it is contrary to the intent of Congress." ${ }^{50}$ The court also stated that "by explicitly creating a 2-year limitation in subsections (b) and (c) but not subsection (f), Congress has 'spoken' by its audible silence." 51

As in Swallows Holding, the Tax Court's decision in Lantz was reversed on appeal. In an opinion by Judge Posner, the Court of Appeals for the Seventh Circuit stated that it 'would not accept 'audible silence' as a reliable guide to congressional meaning. 'Audible silence,' like Milton's 'darkness visible' or the Zen koan 'the sound of one hand clapping,' requires rather than guides interpretation. Lantz's brief translates 'audible silence' as 'plain language,' and adds (mysticism must be catching) that 'Congress intended the plain language of the language used in the statute." ${ }^{52}$ The court further stated that "The delegation in section 6015(f) is express, and the cases are legion that say that Treasury regulations are entitled to judicial deference ...." and deferred to the regulation. ${ }^{53}$

Following that and other decisions upholding the two-year limitations period, the IRS changed its view and issued a Notice stating, "Notwithstanding these court decisions, Treasury and the IRS have concluded that the regulations issued under section 6015 should be revised so that individuals who request equitable relief under section 6015(f) will no longer be required to submit a request for equitable relief within two years of the IRS's first collection activity against the requesting spouse with respect to the joint tax liability." 54

Even more recently, a controversy erupted over regulations interpreting the time period within which the IRS can assess tax (Lederman, 2012, pp. 679-687). The regulations interpreted two Code sections that extend the usual limitations period from three years to six where there was a substantial omission from income. ${ }^{55}$ Under the approach of the regulations, the longer period applies where the omission was caused by the inflation of tax basis outside the context of a trade or business.

Because the regulations were targeted at a well-known tax shelter (commonly known as "Son of BOSS") that had many investors, the regulations were at issue in a number of court cases (Lederman, 2012, p. 679). One of the early decisions was by the Tax Court, which considered the Temporary regulations. It held that the regulations were both not applicable because of the terms of the effective date provision, ${ }^{56}$ and invalid

\footnotetext{
${ }^{50}$ Lantz at 141

${ }^{51}$ Lantz at 139.

${ }^{52}$ Lantz, 607 F.3d at 481.

${ }^{53}$ Lantz at 486. For a critique of Judge Posner's opinion, see Camp (2010).

${ }^{54}$ IRS Notice 2011-70; 2011 IRB LEXIS 416 (July 25, 2011).

${ }^{55}$ See I.R.C. $\S \S 6501(\mathrm{e}) ; 6229(\mathrm{c})(2)$.

${ }^{56}$ Intermountain Ins. Serv. of Vail, LLC v. Comm'r, 134 T.C. 211, 220 (2010) (reviewed by the court), rev'd, 650 F.3d 691 (D.C. Cir. 2011).
} 
and therefore not entitled to deference. ${ }^{57}$ The Tax Court reached the conclusion that the regulations were invalid because it found that, under the first step of Chevron, the statute was unambiguous according to a Supreme Court case, Colony, ${ }^{58}$ that had interpreted a previous version of the statute but had referred to the later version in dicta. ${ }^{59}$ Intermountain was reversed on appeal ${ }^{60}$ but the Fourth and Fifth Circuits also found the regulation inapplicable ${ }^{61}$ in contrast to other circuits that upheld the regulation. ${ }^{62}$

The Supreme Court granted certiorari in the Fourth Circuit case, Home Concrete, ${ }^{63}$ and invalidated the regulation in a divided decision, finding that "Colony has already interpreted the statute, and there is no longer any different construction that is consistent with Colony and available for adoption by the agency." 64 Because the Court found that Colony left no room for agency action, it did not address the question of whether the Treasury can issue a regulation that interprets a statute differently than a prior Supreme Court decision that found a statute capable of multiple interpretations. The Supreme Court had previously held in National Cable \& Telecommunications Ass' $n$ v. Brand $X$ Internet Services, that "A court's prior judicial construction of a statute trumps an agency construction otherwise entitled to Chevron deference only if the prior court decision holds that its construction follows from the unambiguous terms of the statute and thus leaves no room for agency discretion." ${ }^{65}$ However, in Brand $X$, the previous court decision was a Court of Appeals decision, ${ }^{66}$ not a Supreme Court decision, as Chief Justice Roberts noted during the Home Concrete oral argument. ${ }^{67}$

${ }^{57}$ Intermountain at 224.

${ }^{58}$ Colony, Inc. v. Comm'r, 357 U.S. 28 (1958).

59 See Intermountain at 220-24.

${ }^{60}$ Intermountain Ins. Serv. of Vail, LLC v. Comm'r, 650 F.3d 691, 710 (D.C. Cir. 2011) (applying Chevron deference to the final regulations).

${ }^{61}$ See Home Concrete \& Supply, LLC, v. United States, 634 F.3d 249, 256-57 (4th Cir. 2011), noting that the regulation does not apply by the terms of its applicability date and Colony is controlling, so the regulation would not be entitled to Chevron deference anyway, affirmed, 2012 U.S. LEXIS 3274 (2012). And see Burks v. United States, 633 F.3d 347, 355, 360, n.9 (5th Cir. 2011), noting that Colony controls, but it is unclear if Chevron would apply if it did not, given the regulations' retroactivity and litigation focus.

${ }^{62}$ See Grapevine Imports, Ltd. v. United States, 636 F.3d 1368, 1380-81 (Fed. Cir. 2011), granting Chevron deference and finding arguments regarding procedural defects in the temporary regulations mooted by the issuance of the final regulations. And see Salman Ranch, Ltd. v. Commissioner, 647 F.3d 929, 939-40 (10th Cir. 2011), similarly applying Chevron deference to the final regulations and finding that arguments regarding the temporary regulations were mooted by the issuance of the final regulations.

${ }^{63}$ See United States v. Home Concrete \& Supply, LLC, 132 S. Ct. 71 (2011) (granting certiorari).

${ }^{64}$ United States v. Home Concrete \& Supply, LLC, 2012 U.S. LEXIS 3274, pp. 14-15 (2012).

65545 U.S. 967,982 (2005).

${ }^{66}$ See Brand $X$ at 979-80 (applying AT\&T Corp. v. Portland, 216 F.3d 871 (9th Cir. 2000)).

${ }^{67}$ See Transcript of Oral Argument at 55, United States v. Home Concrete \& Supply, LLC, No. 11-139 (U.S. Jan. 17, 2012), http://www.supremecourt.gov/oral_arguments/argument_transcripts/11-139.pdf, in which Chief Justice Roberts states, "We've never said an agency can change what we've said the law means." 


\section{STANDING ISSUES}

The regulations discussed above all imposed restrictions on taxpayers, either limiting their ability to make a claim, or, in the case of Intermountain, resulting in a longer period for assessment of tax. What about regulations that are arguably more generous than a statute, resulting in forgone revenue to the federal fisc, for which we all pay indirectly? Polsky (2009, p. 239) has explained that, "[i]n general, taxpayers do not have standing in a suit that concerns someone else's taxes because the relief sought would not benefit the taxpayer in any tangible way. In other words, a person does not have standing to challenge a tax rule merely because of one's status as a taxpayer; rather, the person must suffer a tangible injury in order to challenge the validity of a regulation."

For example, in DiamlerChrysler Corp. v. Cuno ${ }^{68}$ the Supreme Court ruled that in order for the taxpayers to have standing to challenge an Ohio franchise tax credit, they had to satisfy the requirement in Article III of the U.S. Constitution that there be an actual case or controversy. ${ }^{69}$ The Court stated, "The requisite elements of this "core component derived directly from the Constitution' are familiar: 'A plaintiff must allege personal injury fairly traceable to the defendant's allegedly unlawful conduct and likely to be redressed by the requested relief." "'70

More recently, in Arizona Christian School Tuition Organization v. Winn ${ }^{71}$ the Supreme Court considered a Constitutional challenge to a state tax credit for contributions to school tuition organizations, which "use these contributions to provide scholarships to students attending private schools, many of which are religious." ${ }^{.72}$ The Court explained that the "case or controversy" requirement of Article III requires standing. ${ }^{73}$ The Court then reiterated the general rule against taxpayer standing:
Absent special circumstances . . standing cannot be based on a plaintiff's mere status as a taxpayer. This Court has rejected the general proposition that an individual who has paid taxes has a "continuing, legally cognizable inter- est in ensuring that those funds are not used by the Government in a way that violates the Constitution." . . . This precept has been referred to as the rule against taxpayer standing. ${ }^{74}$

Thus, in general, the remedy for a taxpayer with a general grievance about how the government spends its money is not through the courts. Instead, the taxpayer must use

\footnotetext{
${ }^{68}$ See 547 U.S. 332 (2006).

${ }^{69}$ DiamlerChrysler at 342.

${ }^{70}$ DiamlerChrysler at 342 (quoting Allen v. Wright, 468 U.S. 737, 751 (1984)).

${ }^{71}$ See 131 S. Ct. 1436 (2011).

72 Arizona Christian School Tuition Organization at 1440.

${ }^{73}$ Arizona Christian School Tuition Organization at 1442.

${ }^{74}$ Arizona Christian School Tuition Organization at 1442-43 (citations omitted).
} 
the political system and attempt to get the government to change its policies. However, in Arizona Christian School Tuition Organization, the Court further pointed out that Flast v. Cohen established an exception to the rule against taxpayer standing:

Flast held that taxpayers have standing when two conditions are met.

The first condition is that there must be a "logical link" between the plaintiff's taxpayer status "and the type of legislative enactment attacked." In Flast, ... the allegation was that the Federal Government violated the Establishment Clause in the exercise of its legislative authority both to collect and spend tax dollars. In the decades since Flast, the Court has been careful to enforce this requirement....

The second condition for standing under Flast is that there must be "a nexus" between the plaintiff's taxpayer status and "the precise nature of the constitutional infringement alleged." This condition was deemed satisfied in Flast based on the allegation that Government funds had been spent on an outlay for religion in contravention of the Establishment Clause. ${ }^{75}$

Arizona Christian School Tuition Organization found the Flast exception inapplicable because the case involved tax credits rather than a governmental expenditure. ${ }^{76}$

In some cases involving a taxpayer-friendly regulation or IRS guidance, there might nonetheless be a circumstance in which a taxpayer is in the unusual position of being directly harmed by it and thus able to bring a challenge. For example, with respect to the taxpayer-friendly elective entity classification regime known as "Check-the-Box," Polsky (2004, p. 239) argued:

Because the check-the-box regulations allow an entity to elect its classification, it might appear on first glance that all taxpayers in all instances will fare no worse under the regulations than under [the prior regime]. If this were the case, no one would have standing to challenge the regulations. Although these regulations will generally work to the taxpayer's benefit (or at least not to the taxpayer's detriment), there will be certain situations where the taxpayer would be better off under the corporate resemblance test. One could think of a number of such scenarios....

He went on to provide three examples (Polsky, 2004, pp. 239-243). Those examples were specific to the context of the Check-the-Box regulations, however, so they are not generalizable.

\footnotetext{
75 Arizona Christian School Tuition Organization at 1445 (citations omitted).
}

${ }^{76}$ Arizona Christian School Tuition Organization at 1447-48. 
Another context involving taxpayer-favorable guidance involved a series of publicly criticized Notices the IRS promulgated in 2008 and 2009 liberalizing the provision that limited the use of net operating losses after a change in corporate ownership and apparently benefitting specific taxpayers without naming them (Elliott, 2009; Block, 2010). For example, Notice 2008-83 stated succinctly, "For purposes of section 382(h), any deduction properly allowed after an ownership change (as defined in section 382(g)) to a bank with respect to losses on loans or bad debts (including any deduction for a reasonable addition to a reserve for bad debts) shall not be treated as a built-in loss or a deduction that is attributable to periods before the change date." ${ }^{.77}$ Accordingly, the Notice allowed a bank that acquired another bank not to face the usual limitation on the deduction of the acquired bank's built-in losses (Block, 2010).

Although the Notice did not name a particular taxpayer or taxpayers who would benefit from it, the context in which the Notice was issued was suggestive:

At the time this notice was released, Congress was debating emergency bailout legislation, and Citigroup and Wells Fargo were competing to acquire control of Wachovia. Before the notice, it appeared that Wells Fargo's bid had failed and that Citigroup would acquire Wachovia. According to observers, the tax savings from this dramatic change in IRS interpretation of the $\S 382$ loss limitation rules enabled Wells Fargo, which had actively lobbied for the change, to make a new and successful bid (Block, 2010, pp. 218-219).

The Treasury did not compute the cost of the Notice or seek public input in advance of issuing the Notice. Block (2010, p. 219) notes that, "Some estimated that the overall cost to taxpayers would be between $\$ 100$ billion and $\$ 140$ billion," which includes costs attributable to other taxpayers who made use of the ruling.

It would be difficult to find a taxpayer with standing to challenge this Notice (Shenoi, 2010, p. 551). However, Notice 2008-83 angered Congress and provoked it to rebuke the Treasury, stating, in an off-Code provision:

(a) Findings - Congress finds as follows:

(1) The delegation of authority to the Secretary of the Treasury under section 382(m) of the Internal Revenue Code of 1986 does not authorize the Secretary to provide exemptions or special rules that are restricted to particular industries or classes of taxpayers.

${ }^{77}$ Notice 2008-83, 2008-2 C.B. 905, at $§ 2$. The Notice also stated, "The Internal Revenue Service and Treasury Department are studying the proper treatment under section 382 (h) of the Internal Revenue Code (Code) of certain items of deduction or loss allowed after an ownership change to a corporation that is a bank (as defined in section 581) both immediately before and after the change date (as defined in section $382(\mathrm{j})$ ). As described below under the heading Reliance on Notice, such banks may rely upon this guidance unless and until there is additional guidance." See Notice 2008-83 at $\S 1$. 
(2) Internal Revenue Service Notice 2008-83 is inconsistent with the congressional intent in enacting such section $382(\mathrm{~m})$.

(3) The legal authority to prescribe Internal Revenue Service Notice 200883 is doubtful. ${ }^{78}$

Congress did, however, grandfather transactions that occurred before January 16, 2009 or took place under a binding written agreement entered into before that date. ${ }^{79}$

\section{CONCLUSION}

As the discussion above shows, despite the importance of the Code, there are several important non-statutory sources of federal tax law. Along with Congress, the courts, the Treasury, and the IRS all play important roles in the development of the tax law. The role of the courts typically is to interpret tax statutes, regulations, and other tax rules and apply the law in cases before them. Court decisions generally have precedential value. However, Congress makes frequent changes to the tax law, and, even if it is not responding to a particular case, the amendments may make prior case law irrelevant. Similarly, the Treasury or IRS may change a regulation or ruling, in which case a court hearing a future case will be faced with a novel question. This nuanced dance among the three branches of government is part of what makes federal tax law so interesting.

\section{ACKNOWLEDGMENTS}

The author would like to thank Bryan Camp, Bill Gentry, Kristin Hickman, and Joshua Odintz for helpful comments on a prior draft; participants in the 2012 National Tax Association Spring Symposium for helpful discussions; and Karun Ahuja, Donald Bierer, Jennifer Hepp, and Michele Roberts for valuable research assistance.

\section{REFERENCES}

Aprill, Ellen P., 2012. "The Impact of Agency Guidance Procedures and Judicial Review on Tax Reform.” National Tax Journal 65 (4), 917-932.

Block, Cheryl D., 2010. "Measuring the True Cost of Government Bailout." Washington University Law Review 88 (1), 149-228.

Camp, Bryan T., 2010. “Interpreting Statutory Silence.” Tax Notes 128 (3), 501-515.

Chapman, Robert B., 2002. “Bankruptcy.” Mercer Law Review 53 (4), 1199-1313.

\footnotetext{
${ }^{78}$ American Recovery and Reinvestment Act of 2009, Pub. L. No. 111-5, § 1261(a), 123 Stat. 115, 342-43.

${ }^{79}$ American Recovery and Reinvestment Act of 2009 at $\S 1261(\mathrm{~b})$.
} 
Cohen, Mary Ann, 2001. "How to Read Tax Court Opinions." Houston Business and Tax Law Journal 1, 1-11.

Cords, Danshera, 2008. "Administrative Law and Judicial Review of Tax Collection Decisions." Saint Louis University Law Journal 52 (2), 429-478.

Crimm, Nina, 1999. Tax Court Litigation: Practice and Procedure. Aspen Law and Business Publishers, New York, NY.

Elliott, Amy S., 2009. "Year in Review: Treasury Provides Certainty and Relief in Economic Crisis.” Tax Notes 122 (Jan. 5), 47-49.

Gall, Phillip (2003). "Phantom Tax Regulations: The Curse of Spurned Delegations," Tax Lawyer $56(2), 413-450$.

Germain, Gregory, 2004. "Discharging Their Duty: A Critical Assessment of the Tax Court's Refusal to Consider Bankruptcy Discharge Questions.” Virginia Tax Review 23 (3), 531-613.

Hickman, Kristin E., 2007. "Coloring Outside the Lines: Examining Treasury's (Lack Of) Compliance with Administrative Procedure Act Rulemaking Requirements." Notre Dame Law Review 82 (5), 1727-1807.

Hickman, Kristin E., 2009. "IRB Guidance: The No Man's Land of Tax Code Interpretation." Michigan State Law Review 2009 (1), 239-272.

Hickman, Kristin E., forthcoming. "Unpacking the Force of Law." Vanderbilt Law Review.

Jois, Goutam U., 2009. “Stare Decisis Is Cognitive Error.” Brooklyn Law Review 75 (1), 63-141.

Laro, David, 1995. "The Evolution of the Tax Court as an Independent Tribunal." University of Illinois Law Review 1995 (1), 17-29.

Lederman, Leandra, 1996. "“Civil'izing Tax Procedure: Applying General Federal Learning to Statutory Notices of Deficiency.” University California at Davis Law Review 30 (1), 183-245.

Lederman, Leandra, 2001. "Equity and the Article I Court: Is the Tax Court's Exercise of Equitable Powers Constitutional?" Florida Tax Review 5 (5), 357-411.

Lederman, Leandra, 2012. “The Fight Over 'Fighting Regs' and Judicial Deference in Tax Litigation.” Boston University Law Review 92 (2), 643-700.

Lederman, Leandra, and Stephen W. Mazza, 2009. Tax Controversies: Practice and Procedure. LexisNexis, Newark, NJ.

Mann, Roberta, 2012. "Chief Counsel's Subtle Impact on Revenue: Regulations, Litigation, and Administrative Guidance.” National Tax Journal 65 (4), 889-898.

Nelson, William F., and James J. Keightley, 1988. "Managing the Tax Court Inventory.” Virginia Tax Review 7 (3), 451-483.

Polsky, Gregg D., 2004. “Can Treasury Overrule the Supreme Court?” Boston University Law Review 84 (1), 185-246. 
Sanchirico, Chris William, 2008. "The Tax Advantage to Paying Private Equity Fund Managers with Profit Shares: What Is It? Why Is It Bad?" University of Chicago Law Review 75 (3), 1071-1153.

Shenoi, Sunil, 2010. "Undoing Undue Favors: Providing Competitors with Standing to Challenge Favorable IRS Actions." University of Michigan Journal of Law Reform 43 (2), 531-568 (Student Note).

Smith, Andre L., 2007. "Formulaically Describing 21st Century Supreme Court Tax Jurisprudence." Houston Business and Tax Law Journal 8 (1), 37-89.

Staudt, Nancy C., Renee Lindstadt, and Jason O'Connor, 2007. “Judicial Decisions as Legislation: Congressional Oversight of Supreme Court Tax Cases, 1954-2005," New York University Law Review 82 (5), 1340-1402. 